\title{
Geenit alkion tiineyttämiskyvyn takana
}

Kati Korhonen ${ }^{1}$, Nasser Ghanem ${ }^{2}$, Dawit Tasfaye ${ }^{2}$, Mervi Räty ${ }^{1}$, Elise Ketoja ${ }^{1}$, Timo Tiirikka ${ }^{1}$, Johanna $\mathrm{Aro}^{3}$, Hannu Myllymäki ${ }^{3}$, Johanna Vilkki ${ }^{1}$ ja Jaana Peippo ${ }^{1}$

${ }^{1}$ MTT Biotekniikka- ja elintarviketutkimus, 31600 Jokioinen, etunimi.sukunimi@mtt.fi

${ }^{2}$ University of Bonn, Institute of Animal Science, 53115 Bonn

${ }^{3}$ Alkiokeskus Oy, Urheilutie 6, 01301 Vantaa

\section{Tiivistelmä}

Nykyaikaisessa karjanjalostuksessa huippuemien jälkeläismäärää voidaan lisätä alkiohuuhtelujen avulla. Huuhdeltavan eläimen munasarjat aktivoidaan hormoneilla, jolloin ovulaatiossa irtoaa kerralla jopa kymmeniä munasoluja. Eläin keinosiemennetään, ja hedelmöittyneiden munasolujen annetaan kehittyä seitsemän vuorokautta ennen kuin ne huuhdellaan kohdusta ulos. Heti huuhtelun jälkeen tuoreena siirretyistä alkioista noin $50 \%$ tiineyttää vastaanottajan.

Vastaanottajaeläimen tiinehtymiseen vaikuttaa useita tekijöitä, joista siirrettävän alkion elinkyky on yksi tärkeimmistä. Nykyisin alkion elinkyky arvioidaan ennen vastaanottajaan siirtoa silmämääräisellä mikroskooppitutkimuksella. Menetelmä on kuitenkin vain suuntaa antava. Tässä tutkimuksessa haluttiin selvittää, onko tiineyttävien alkioiden geenitoiminnassa tai aineenvaihduntareiteissä eroa ei-tiineyttäneisiin alkioihin. Jos näin olisi, voitaisiin alkioiden elinkyvyn arviointi tehdä tarkemmin geenitoimintaan perustuen ja näin mahdollisesti parantaa tiineystuloksia.

Tutkimusta varten huuhtelualkioista otettiin pieni näytepala ennen vastaanottajaan siirtoa. Tiineystuloksen selvittyä nämä pakastetut näytepalat ryhmiteltiin tiineyttäneisiin $(\mathrm{T})$ ja ei-tiineyttäneisiin (ET). Koeryhmien geenitoimintaa tutkittiin näytepaloista mikrosirutekniikalla, joka mahdollistaa tuhansien geenien aktiivisuuden mittaamisen samanaikaisesti.

Mikrosirutulosten perusteella löydettiin kymmeniä geenejä joiden aktiivisuus erosi merkittävästi tiineyttäneiden ja ei-tiineyttäneiden alkioiden välillä. Tulosten varmistamiseksi kahdeksan mielenkiintoisimman geenin aktiivisuusero koeryhmien välillä tarkastettiin vielä qPCR-menetelmällä. Sen perusteella varmennettiin kolme geeniä (CKS2, SSPB1 ja H3F3A), joiden aktiivisuus todella oli tiineyttäneissä alkioissa selvästi ei-tiineyttäneitä korkeampi. Näistä geeneistä kaksi, H3F3A ja SSPB1, ovat solun yleisiin toimintoihin liittyviä ylläpitogeenejä. H3F3A tuottaa solunjakautumisesta riippumatonta histoni-proteiini joka on osa DNA:n perusrakennetta, ja SSPB1 ylläpitää mitokondrioiden normaalia toimintaa. CKS2 sen sijaan liittyy alkionkehityksen kannalta tärkeään solunjakautumiseen ja voisi näin ollen toimia alkion elinkyvystä kertovana merkkigeeninä.

Yksittäisten geenien lisäksi löydettiin kaksi tiineyttäneille alkioille ominaista aineenvaihduntareittiä; folaattisynteesi ja ribosomien toimintaan liittyvä reitti. B-ryhmän vitamiineihin kuuluva folaatti on tärkeä tekijä normaalissa alkionkehityksessä, ja ribosomien toiminta liittyy alkionkehityksen kannalta välttämättömiin proteiinisynteeseihin. Aineenvaihduntareittien löytyminen antaa yksittäisiä geenejä laajempaa tietoa siitä minkälaiset mekanismit tiineyttävissä alkioissa ovat toiminnassa.

Tämä tutkimus on osa neljävuotista (2006-2009) EU:n rahoittamaa SABRE-projektia.

Asiasanat: in vivo, alkion elinkyky, qPCR, mikrosiru 


\section{Johdanto}

Alkutiineyden aikana tapahtuvat alkiokuolemat ovat yksi merkittävä maidon- ja lihantuotannon kannattavuuteen vaikuttava tekijä. On arvioitu, että 28-43\% kaikista tiineyksistä abortoituu ennen 16 vuorokautta (Diskin ja Morris 2008). Tärkeimmät syyt varhaisiin alkiokuolemiin löytyvät alkion heikosta elinkyvystä, emän kohdun epäoptimaalisesta fysiologisesta tilasta, epäsynkroniasta emän kiimankierron vaiheen ja alkion iän välillä, sekä ongelmista alkion ja emän välisessä hormonaalisessa kommunikoinnissa (Rodriguez-Zas ym. 2008, El-Sayed ym. 2006).

Kun keskitytään onnistuneen tiineyden tutkimiseen alkion elinkyvyn näkökulmasta, nousevat geenit tärkeään asemaan. Aiempien tutkimusten perusteella tiedetään, että normaali alkionkehitys on geenien tarkan yhteistoiminnan tulosta. Esimerkiksi alkion kohtuun kiinnittymisen voi estää virhe pelkästään yhden geenin toiminnassa (Niemann ym. 2007, Copp 1995).

Tutkimuksia, joissa tuhansia alkion elinkykyyn liittyviä geenejä olisi tutkittu samanaikaisesti, on vielä vähän. Osittain tämä johtuu siitä, että näihin tutkimuksiin soveltuva tekniikka -mikrosirut ja erityisesti toisen sukupolven sekvensointilaitteet- on kohtalaisen uutta. Vuonna 2006 El-Sayed ja kumppanit raportoivat mikrosirututkimuksensa tuloksena löydettyjä geenejä, joiden aktiivisuus liittyi laboratoriossa kasvatettujen in vitro alkioiden tiineyttämiskykyyn. He totesivat että tiineyttävissä alkioissa erityisen aktiivisia (up-reguloituja) olivat geenit, joita tarvitaan alkion kohtuun kiinnittymisessä (COX2, CDX2), hiilihydraattimetaboliassa (ALOX15), solujen kasvussa ja erilaistumisessa (BMP15), signaalien välityksessä soluissa (PLAU) ja istukan kehityksessä (PLAC8). Ei-tiineyttäneissä alkioissa aktiivisia olivat puolestaan geenit, jotka liittyvät sytokiinien ilmestymiseen tulehdusreaktioissa (TNF), aminohappojen sitoutumiseen (EEF1A1), transkriptiotekijöihin (MSX1, PTTG1), glukoosimetaboliaan (PGK1, AKR1B1) ja alkion kohtuun kiinnittymistä estäviin tekijöihin (CD).

Tuoresiirtoihin, joissa tiinehtyminen on todennäköisintä, voidaan valita vain yksi alkio. Nykyisin alkion elinkyky arvioidaan ennen vastaanottajaan siirtoa silmämääräisellä mikroskooppitutkimuksella. Menetelmä on kuitenkin subjektiivinen, ja on todettu, että $25 \%$ :ssa elinkykyisiksi luokitelluista in vivo alkioista on kromosomaalisia epänormaaliuksia (Viuff ym. 1999).

Tässä työssä tutkittiin in vivo huuhtelualkioiden geenitoimintaa tavoitteena löytää alkion hyvästä tiineyttämiskyvystä kertovia merkkigeenejä ennen siirtoa tehtävän elinkyvynarvioinnin tarkentamiseksi. Vastaavaa in vivo alkioiden geenitoiminnan tutkimusta ei ole aikaisemmin julkaistu.

\section{Aineisto ja menetelmät}

Huuhdeltaville eläimille aiheutettiin superovulaatio, eli useiden munasolujen samanaikainen irtoaminen hormonipistoshoidolla. Eläimet keinosiemennettiin ovulaatiopäivänä. Alkiot huuhdeltiin luovuttajaeläinten kohduista seitsemän vuorokauden kuluttua siemennyksestä. Huuhtelun jälkeen alkioiden kehitysaste ja laatuluokka (I-III) arvioitiin mikroskoopin avulla. Vain laatuluokkaan I kuuluvat alkiot valittiin tutkimukseen. Niistä leikattiin pieni näytepala eli biopsia silmäkirurgin veitsellä mikroskoopin avulla. Biopsian koko oli n. 40 \% alkion kokonaissolumassasta, ja se sisälsi sekä ulko- että sisäsolumassan soluja. Biopsianäytteet pakastettiin.

Biopsioidut alkiot siirrettiin tuoreena vastaanottajiin, joiden kiimankierto oli synkronoitu hormonipistoshoidolla sopivaan vaiheeseen. Jos vastaanottaja tuli kiimaan 21 vrk kuluttua siirrosta, tai myöhemmin, merkittiin eläin ei-tiineet -ryhmään. Tiineitä vastaanottajia seurattiin vasikan syntymään asti, jolloin eläin merkittiin tiineet-ryhmään. Kun kaikkien vastaanottajien tiineystulokset oli varmistettu, yhdistettiin sekä tiineyttäneiden alkioiden (T) biopsiat, että ei-tiineyttäneiden alkioiden (ET) biopsiat kolmeksi näytteeksi (jokainen näyte sisälsi kolme biopsiaa).

Kolmesta T ja ET -näytteestä eristettiin lähetti-RNA Dynabead oligo (dT) $)_{25}$-kitillä, ja käännettiin se cDNA:ksi Superscript II -entsyymillä. Saatu cDNA monistettiin käyttäen DOP-alukkeita ja PCRmaster -kittiä. Monistettu cDNA käännettiin aRNA:ksi Ampli-Scribe T7 transcription -kitillä. Käännetty aRNA puhdistettiin RNeasy mini -kitillä, ja sen saanto ja puhtaus tarkastettiin spektrofotometrillä. Saatu aRNA käännettiin aminoallyyli leimatuksi cDNA:ksi Amersham Postlabeling -kitin avulla. T ja ET -näytteet (nyt siis aminoallyyli leimattuina cDNA:na) leimattiin kumpikin omalla fluoresoivalla värillään (Cy3 ja $\mathrm{Cy} 5)$. Leimatut näytteet hybridisoitiin mikrosiruille, jotka tässä työssä olivat BlueChipin cDNA -siruja. 
cDNA:n hybridisoituminen siruille määritettiin GenePix 4000B -skannerin avulla. Saatu raakadata esikäsiteltiin, normalisoitiin ja kandidaattigeenilistat luotiin SAM-ohjelmistolla. Mikrosirutulokset raportoitiin suhteellisten aktiivisuuserojen muutoksina (eng. fold change) koeryhmien välillä.

Kandidaattigeenilistoista valittujen mielenkiintoisimpien geenien todelliset aktiivisuuserot koeryhmien välillä mitattiin ylimääräisistä alkiobiopsianäytteistä ( $T$ ja $E T)$ reaaliaikaisella $q P C R-$ menetelmällä (ABI Prism 7000 SDS instrument/SYBR green kemia). Jokaiselle tutkittavalle geenille luotiin standardisuora $\left(10^{1}-109\right)$ plasmidikloonauksen avulla. Näytteiden väliset erot lähtömateriaalin, eli alkiosolujen määrässä tasattiin GAPDH-kontrolligeenin näytekohtaisten tulosten perusteella. Oletuksenahan on että GAPDH- geenin aktiivisuus on vakio jokaisessa solussa. Varsinainen PCRreaktiotilavuus oli $20 \mu \mathrm{l}$ sisältäen templaatin, geenikohtaiset alukkeet, SYBR greenin ja veden. Varsinaisen monistusreaktion jälkeen $\left(95^{\circ} \mathrm{C} 3 \mathrm{~min},\left(95^{\circ} \mathrm{C} 15 \mathrm{~s}, 60^{\circ} \mathrm{C} 30 \mathrm{~s} \times 40\right)\right)$ näytteet ajettiin ns. Dissociaatio-ohjelmalla, jolla varmistettiin monistustuotteen puhtaus ja näin tulosten luotettavuus. qPCRtulokset raportoitiin suhteellisten aktiivisuuserojen muutoksina (eng. relative expression) tutkittavien ryhmien välillä.

\section{Tulokset ja tulosten tarkastelu}

\section{Kandidaattigeenit}

Mikrosirutekniikka mahdollisti tuhansien geenien yhtäaikaisen aktiivisuuden mittauksen alkiobiopsianäytteistä ( $\mathrm{T}=$ tiineyttäneet ja $\mathrm{ET}=$ ei-tiineyttäneet alkiot). Geenien aktiivisuuserot $\mathrm{T}$ - ja ET-alkioiden välillä määritettiin mikrosirutuloksista $\mathrm{SAM}$-ohjelmistoa käyttäen ( $\mathrm{FDR} \leq 5 \%, \mathrm{P} \leq 0.05)$, ja näin saatiin ns. kandidaattigeenilistat. Näissä listoissa (taulukot 1 ja 2) ovat geenit, joiden aktiivisuusero T- ja ET-alkioiden välillä oli yli 1,4 kertainen. Löydetyistä geeneistä 45 oli tiineyttäneissä alkioissa upreguloitua, ja 21 down-reguloitua. Kandidaattigeeneistä valittiin lupaavimmat geenit qPCRvarmennukseen (Up-reguloidut: LDHB, SSPB1, Aurora-A, H3F3A, CKS2 ja down-reguloidut: SVIL, ATP11C, LOC50, HSPCB) koeryhmien välisen aktiivisuuseron ja geenien toimintaan liittyvien taustatietojen perusteella.

Taulukko 1. Tiineyttäneiden alkioiden down-reguloidut geenit.

\begin{tabular}{|l|c|c|}
\hline Geenin nimi & $\begin{array}{c}\text { Aktiivisu } \\
\text { usero }\end{array}$ & Biologinen prosessi johon geeni liittyy \\
\hline EST from a microgravity versus gravity subtracted library from & 4,0 & Tuntematon \\
\hline Supervillin (SVIL) & 2,8 & Solun tukirangan muodustuminen \\
\hline Homo s. mRNA for ATPase, Class VI, type 11C (ATP11C) & 2,6 & ATP biosynteesi, Fosfolipidien kuljetus \\
\hline mRNA for aromatase cytochrome P450 pseudogene (LOC50) & 2,4 & Tuntematon \\
\hline Heat shock 90kDa protein 1, beta (HSPCB) & 2,0 & Stressivaste, Istukan kehitys \\
\hline Proline-rich nuclear receptor coactivator 1 & 1,6 & Tuntematon \\
\hline Homo s. myos in regulatory light chain interacting protein & 1,6 & Solujen liike, Hermoston kehitys \\
\hline Partial mRNA for non-selenium glutathione phospholipid & 1,5 & Lipidien katabolia, Hapettumisen estäminen \\
\hline Similar to chromosome 15 open reading frame 23 & 1,5 & Proteiinien sitoutuminen \\
\hline Sus scrofa mRNA, clone:AMP010031A04, expressed in alveolar \\
macrophage & 1,5 & Tuntematon \\
\hline Polymerase (DNA-directed), delta interacting protein 2 & 1,4 & Tuntematon \\
\hline Similar to Securin (Pituitary tumor-trans forming protein) & 1,4 & DNAn korjaus, solusykli \\
\hline
\end{tabular}


Taulukko 2. Tiineyttäneiden alkioiden up-reguloidut geenit.

\begin{tabular}{|c|c|c|}
\hline Geenin nimi & $\begin{array}{c}\text { Aktiivisu } \\
\text { usero }\end{array}$ & Biologinen prosessi johon geeni liittyy \\
\hline Lactate dehydrogenase B (LDHB) & 8,0 & L-laktaatti dehydrogenaasi aktiivisuus \\
\hline Similar to single-stranded DNA binding protein 1 (SSPB1) & 3,2 & DNAn kahdentuminen \\
\hline Aurora-A & 2,8 & $\begin{array}{c}\text { Solusykli, Proteiinien } \\
\text { aminohappofos forylaatio }\end{array}$ \\
\hline $\mathrm{H} 3$ histone, family $3 \mathrm{~A}(\mathrm{H} 3 \mathrm{~F} 3 \mathrm{~A})$ & 2,4 & $\begin{array}{l}\text { Nukleosomien koostaminen (ei DNAn } \\
\text { kahdentumiseen liittyvä) }\end{array}$ \\
\hline Bubalus bubalis clone pDS5.6 satellite sequence & 2,4 & Tuntematon \\
\hline Homo s. NADH dehydrogenase subunit 5 (MTND5) & 2,1 & NADH dehydrogenase activity \\
\hline Homo s. SRY (s ex determining region Y) NAbox 4 (SOX4) & 2,0 & Solusyklin ja apoptoosin säätely \\
\hline Beta-actin (ACTB) & 1,9 & $\begin{array}{c}\text { ATPn, nukleotidien ja proteiinien } \\
\text { sitoutuminen }\end{array}$ \\
\hline Homo sapiens keratin 18 (KRT18) & 1,9 & Solusyklin ja apoptoosin säätely \\
\hline Clone IMAGE:7961461 beta-2-microglobulin mRNA & 1,8 & Immuunivaste \\
\hline Annexin A2 (ANXA2) & 1,8 & Angiogeneesi, fibrinolyysi \\
\hline Ribosomal protein $\mathrm{S} 27 \mathrm{a}$ & 1,6 & Translaatio \\
\hline Homo s. poly(A) binding protein, cytoplasmic 1 & 1,6 & RNAn pilkkominen, mRNAn käsittely \\
\hline MAP kinase phosphatase-1 & 1,6 & Proteiinien aminohappodefos forylaatio \\
\hline Proline-rich nuclear receptor coactivator 1 & 1,5 & Res eptorien aktiivisuus \\
\hline Oocyte-secreted protein variant 2 (OOSP1) & 1,5 & Tuntematon \\
\hline Ribosomal protein $\mathrm{S} 18$ & 1,5 & Translaatio \\
\hline Placenta-specific 8 (PLAC8) & 1,5 & Tuntematon \\
\hline Homo s. chromosome 3 open reading frame 59 & 1,5 & Tuntematon \\
\hline Sushi repeat-containing protein & 1,5 & Tuntematon \\
\hline Ubiquitin-like/S30 ribos omal fusion protein (FAU) & 1,5 & Translaatio \\
\hline CDC28 protein kinase regulatory subunit 2 (CKS2) & 1,5 & Solusyklin säätely \\
\hline Homo s. F-box protein 5, (FBXO5) & 1,5 & Solusyklin säätely \\
\hline Intestinal alkaline phosphatase III (ALPI) & 1,4 & Aineenvaihdunta prosessit \\
\hline Sodium channel, voltage-gated, type III beta, (SCN3B) & 1,4 & Ionien kuljetus \\
\hline Pea Chloroplast $4.5 \mathrm{~S}, 5 \mathrm{~S}, 16 \mathrm{~S}$ and $23 \mathrm{~S}$ mRNA & 1,4 & Tuntematon \\
\hline Cisplatin resistance-associated overexpressed protein & 1,4 & $\begin{array}{l}\text { RNAn pilkkominen, mRNAn käsittely, } \\
\text { apoptoosi, stressivaste }\end{array}$ \\
\hline Homo s. serine/threonine protein kinase Kp 78 splice variant & 1,4 & Tuntematon \\
\hline
\end{tabular}




\section{Tiineyttäneiden alkioiden up- ja down-reguloitujen geenien varmennustulokset}

Geenien aktiivisuus koeryhmissä varmennettiin qPCR-menetelmällä, koska tiedetään että mikrosirutulosten joukossa voi olla vääriä negatiivisia tai positiivisia tuloksia. Näytteinä käytettiin kokeen aikana kerättyjä ylimääräisiä alkiobiopsioita molemmista koeryhmistä.

Up-reguloitujen geenien (LDHB, SSPB1, Aurora-A, H3F3A ja CKS2) varmennustulokset testattiin tilastollisesti geeniryhmänä, ja todettiin että tiineyttäneissä alkioissa nämä geenit todella olivat merkittävästi $(\mathrm{P}<0.05)$ aktiivisempia kuin ei-tiineyttäneissä alkioissa. Geeneistä kolme, H3F3A, SSPB1 ja CKS2, olivat tiineyttäneissä alkioissa merkittävästi ( $\mathrm{P}=0.02, \mathrm{P}=0.01$ ja $\mathrm{P}=0.0008)$ aktiivisempia myös yksittäin tarkasteltuna. Geenien aktiivisuuserot kolmen biologisen toistonäytteen välillä olivat samankaltaiset tiineyttäneet ja ei-tiineyttäneet ryhmissä. H3F3A ja SSPB1 geenien aktiivisuudet osoittivat kuitenkin suurempaa hajontaa ei-tiineyttäneissä alkionäytteissä verrattuna tiineyttäneisiin alkionäytteisiin.

Tiineyttäneiden alkioiden down-reguloitujen geenien (SVIL, ATP11C, LOC50 ja HSPCB) varmennustuloksia testattiin tilastollisesti geeniryhmänä, ja todettiin että tiineyttäneissä alkioissa nämä geenit todella olivat merkittävästi $(\mathrm{P}=0.008)$ vähemmän aktiivisia kuin ei-tiineyttäneissä alkioissa. Kun geenejä tarkasteltiin yksittäin, ei kuitenkaan yhdenkään geenin aktiivisuus tilastollisesti merkittävästi eronnut ei-tiineyttäneiden ja tiineyttäneiden alkioiden välillä (Kuva 1).

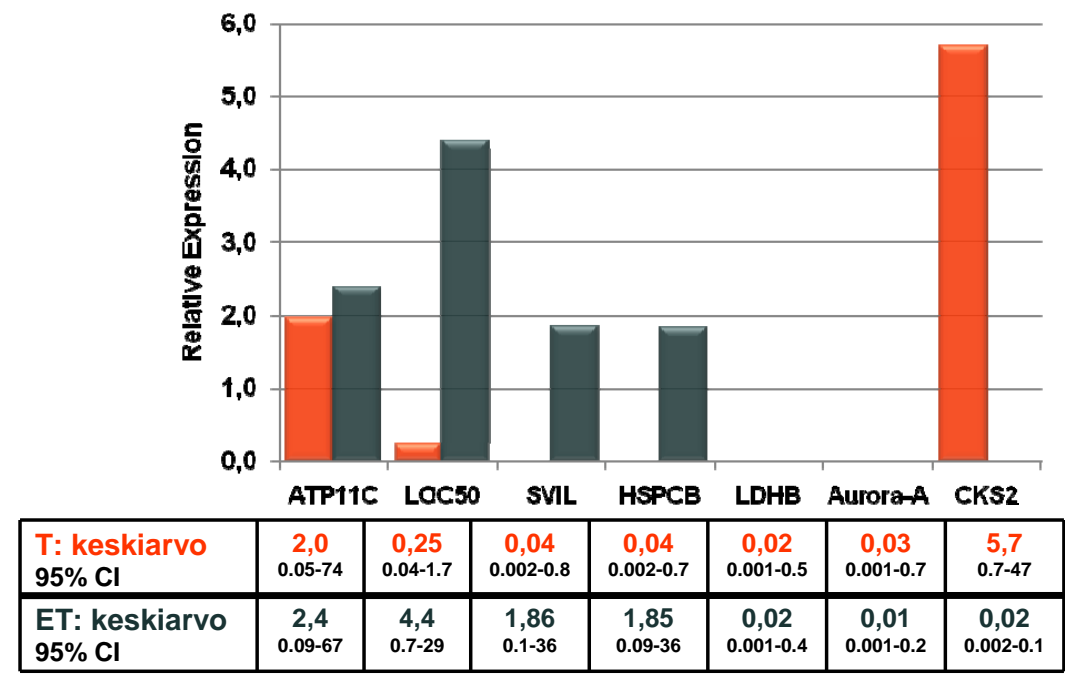

*

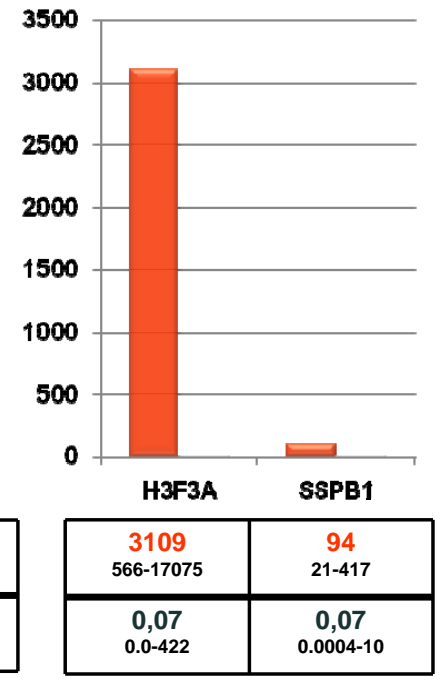

*

Kuva 1. Valittujen geenien aktiivisuus koeryhmissä varmennettiin qPCR-menetelmällä.

*Geenit joiden aktiivisuusero koeryhmien välillä on tilastollisesti merkitsevä $(\mathrm{P}>0.05)$.

\section{Geeniontologiat ja geeniverkot}

Kandidaattigeenilistat (taulukot 1 ja 2) analysoitiin myös FatiGO:lla, joka on osa Babelomicsohjelmistoa. FatiGO:n avulla kandidaattigeenit yhdistettiin geeniontologioihin ja -reitteihin. Tulokset osoittivat, että kandidaattigeenien ontologiat (GO-termit) löytyivät pääasiassa ontologiapuu korkeilta tasoilta. Tämä tarkoittaa, että useimpien kandidaattigeenien toiminta on vielä melko tuntematonta. Kuvassa 2 on esitetty geenien GO-termit tasolla 6.

Geeniverkkoja tarkasteltaessa todettiin, että tiineyttäneiden alkioiden down-reguloidut geenit eivät yhdistyneet mihinkään geeniverkkoon. Kaksi tiineyttäneiden alkioiden up-reguloitua geeniä (ALPI ja FAU) yhdistettiin folaattisynteesi- ja ribosomigeeniverkkoihin, järjestyksessä. 

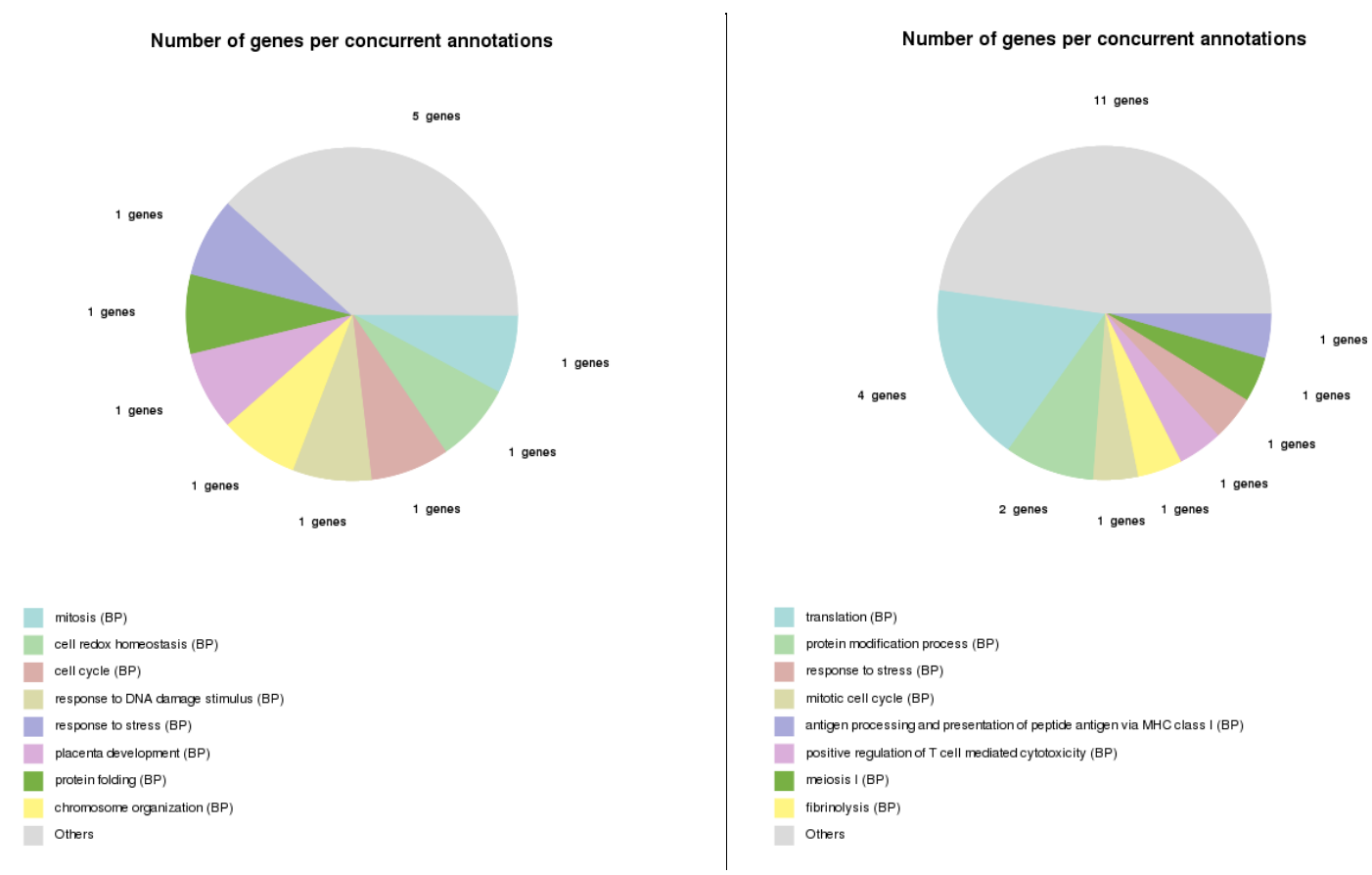

Kuva 2. Tiineyttäneiden alkioiden down-reguloituihin (vasen) ja up-reguloituihin (oikea) geeneihin yhdistetyt GO-termit.

\section{Johtopäätökset}

Tämän tutkimuksen tarkoituksena oli selvittää tiineyttävien alkioiden geenitoimintaa tuhansien geenien tasolla. Valittu mikrosirutekniikka oli sopiva työkalu tämän mittakaavan tutkimukseen. Mikrosirudata analysoitiin ja tuloksena saatiin tiineyttäville alkioille tyypillisiä kandidaattigeenejä ja geenireittejä.

Tiineyttäneiden alkioiden kandidaattigeenilistalta löytyi neljä up-reguloitua geeniä jotka liittyvät solusyklin säätelyyn, kun taas ei-tiineyttäneiden alkioiden listalta tälläisiä geenejä ei löytynyt. Tulos on johdonmukainen, sillä solusyklin säätely ja solujen jakautuminen ovat alkionkehityksen onnistuneen etenemisen kannalta keskeisiä tekijöitä. Tiineyttäneistä alkioista löytyi myös kaksi mielenkiintoista geenireittiä; folaattisynteesi ja ribosomit. Folaatti on yksi B-ryhmän vitamiineista ja tärkeä tekijä normaalissa alkionkehityksessä (Kobus ym. 2009). Ribosomit puolestaan ovat välttämättömiä proteiinisynteesin toiminnassa. Geenireittituloksiin täytyy kuitenkin suhtautua varauksella, sillä molempiin reitteihin liitettiin vain yksi geeni. Näitä geenejä ei myöskään varmennettu qPCR:llä niiden alhaisen koeryhmien välisen aktiivisuuseron takia.

Varmennukseen valitut up-reguloidut geenit osoittivat korkeampaa aktiivisuutta tiineyttäneissä alkioissa myös qPCR -määrityksen perusteella, mutta ainoastaan H3F3A, SPPB1 ja CKS2 geenien osalta aktiivisuusero ryhmien välillä oli tilastollisesti merkitsevä. H3F3A:n tehtävä on tuottaa solunjakautumisesta riippumatonta histoni-proteiini, joka on osa DNA:n perusrakennetta. SSPB1 puolestaan ylläpitää mitokondrioiden normaalia toimintaa. CKS2-geeni ei kuulu kahden muun tavoin solun ylläpitogeeneihin, vaan se on osa alkionkehityksen kannalta tärkeää solunjakautumisen ohjausjärjestelmää.

Alkiosta otetusta näytepalasta voidaan nykyään rutiinisti määrittää alkion sukupuoli. Myös erilaisten tuotantogeenien alleelityyppimäärityksiä on mahdollista tehdä (Peippo ym. 2007). Näitä valmiina olevia tekniikoita soveltamalla myös tiettyjen geenien aktiivisuustasojen määritys ennen alkionsiirtoa olisi mahdollista. Tämän tutkimuksen perusteella CKS2 geenin aktiivisuus voisi toimia indikaattorina alkion tiineyttämiskyvystä. 


\section{Kirjallisuus}

Copp, A. 1995. Death before birth: clues from gene knockouts and mutations. Trends Genet. 11: 87-93.

Diskin, M., and Morris, D. 2008. Embryonic and early foetal losses in cattle and other ruminants. Reprod. Domest. Anim. 43: 260-7. Review.

El-Sayed , A., Hoelker, M., Rings, F., Salilew, D., Jennen, D., Tholen, E., Sirard, M-A., Schellander, K., Tesfaye, D. 2006. Large-scale transcriptional analysis of bovine embryo biopsies in relation to pregnance success after transfer to recipients. Physiol. Genomics 28: 84-96.

Kobus, K., Nazari, E., Muller, Y. 2009. Effects of folic acid and homocysteine on spinal cord morphology of the chicken embryo. Histochem. Cell Biol. 132: 525-32.

Niemann, H., Carnwath, J., Kues, W. 2007. Application of DNA array technology to mammalian embryos. Theriogenology 68: S165-77. Review.

Peippo, J., Viitala, S., Virta, J., Räty, M., Tammiranta, N., Lamminen, T., Aro, J., Myllymäki, H., Vilkki, J. 2007. Birth of correctly genotyped calves after multiplex marker detection from bovine embryo microblade biopsies. Mol. Reprod. Dev. 74: 1373-8.

Rodriguez-Zas, S., Schellander, K., Lewin, H. 2008. Biological interpretations of transcriptomic profiles in mammalian oocytes and embryos. Reproduction 135: 129-39. Review

Viuff, D., Rickords, L., Offenberg, H., Hyttel, P., Avery, B., Greve, T., Olsaker, I., Williams, J., Callesen, H., Thomsen, P. 1999. A high proportion of bovine blastocysts produced in vitro are mixoploid. Biol. Reprod. 60: $1273-8$. 